\title{
Cleaning and Decontamination of Reusable Medical Equipments, Including the use of Hydrogen peroxide Gas Decontamination
}

\author{
BM Andersen ${ }^{1 *}$, K Hochlin ${ }^{1}$ and JP Daling ${ }^{2}$
}

${ }^{1}$ Department of Hospital Infections, Oslo University Hospital, Oslo, Norway

${ }^{2}$ Department of Medical and Technical Equipments, Oslo University Hospital, Oslo, Norway

\section{Summary}

Objectives: Outpatients have increasing need for reusable medical equipments, including respiratory tract equipments. Infection control routines for these devices are often superficial or may even be missing. In the Oslo region, approximately 22000 outpatients are using different forms of medical equipments. The service of reusable medical equipment includes cleaning, reparation, maintenance and replacement of inner or outer parts. This is done periodically or more often when needed, and always before a new user.

Methods: A systematically manual procedure for cleaning (soap and water) and decontamination (heated water at $85^{\circ} \mathrm{C}$ in washing machine or liquid chloramines $5 \%$.) procedure has been developed for all medical equipment received from outpatients. From 2007 on, a gas decontamination method was developed, using $5 \%$ dry mist of hydrogen peroxide gas to decontaminate inner parts of the equipment that could not be soaked in liquids. The equipment was placed in a special sealed gas decontamination room before and after maintenance procedures. Control of gaseous decontamination was done with spore tests placed in internal parts of the equipment and in the decontamination room.

Results: Medical equipments received from outpatients were often heavily contaminated inside with dirt, dust and biological materials like secrete, excrete and blood rests. The use of hydrogen peroxide dry mist killed all control spores placed in the decontamination room and $90 \%$ of the spores placed in internal parts of the equipment.

Conclusion: A combined manual and hydrogen peroxide dry mist decontamination of medical equipment may reduce the risk of transmitting infectious materials between patients, personnel, environment and healthcare institutions. The dry mist of hydrogen peroxide used in this study did not corrode or destroy the sensitive internal parts of the equipments and got access to most internal parts of the equipment, as demonstrated by the spore tests.

Keywords: Medical equipment; Reusable devices; Internal parts; Cleaning and decontamination methods; Hydrogen peroxide dry mist; Infection control; Hygie

\section{Introduction}

The increasing spread of pathogenic microbes, like MRSA (methicillin - resistant Staphylococcus aureus), VRE (vancomycin resistant enterococci), and other multi-drug resistant bacteria, including Gram-negative bacilli with the new New Dehli metallobeta-lactamase -1 (NDM-1), is of global concern [1-5]. Microbes may follow patients, personnel, equipments and other items - all over the world and be a part of the environment where they are introduced [1-6]. There are no boundaries for microbes as far as they are robust enough and survive in the environment. This triggers increased need of good hygienic routines based on isolation, cleaning and disinfection of environment and equipment [7-14].

In Norway, liquid chemicals like chlorine, 5\% chloramines and peracetic acid, have traditionally been used for manual surface disinfection, for terminal decontamination of isolation rooms, furniture, ambulances, and for medical and other equipment after use for infectious patients [7]. Devices with electric equipment and motors can, however, not be soaked in liquid chemicals or in hot water. Therefore, a dry mist of $5 \%$ hydrogen peroxide disinfectant has been developed to disinfect problem-areas like internal parts of equipment, ambulances and special rooms [8]. A dry mist of $5 \% \mathrm{H}_{2} \mathrm{O}_{2}$ is used instead of wet $\mathrm{H}_{2} \mathrm{O}_{2}$ gas since the wet gas is associated with corrosion of metals [8].

Outpatients may need reusable medical equipment for different reasons, like chronic obstructive pulmonary disease (COPD), special nutrition problems, and the need for dialyses and wound suction. The mechanical devices are often following the patient to and from healthcare institutions, like respiratory tract equipment (ventilators, different continuous positive air pressure systems (CPAP) with or without humidifier and cough-assistants), and different infusion- and nutrient pumps, wound suction systems and other suction equipments.

The devices usually takes air from the patients environment to cool the motor or to be used for instance in an oxygen concentrator. The internal parts may then be contaminated by airborne microbes, secrets and dust which is dependent on the infectious state of the patient and the burden of biological materials and the cleanliness of the environment [15-17].

In this study, a systematic method to clean and decontaminate internal components of reusable medical equipments of outpatients is described.

*Corresponding author: Andersen BM, Department of Hospital Infections, Oslo University Hospital, Oslo, Norway, E-mail: bomarand@hotmail.com

Received February 14, 2012; Accepted March 26, 2012; Published April 02, 2012

Citation: Andersen BM, Hochlin K, Daling JP (2012) Cleaning and Decontamination of Reusable Medical Equipments, Including the use of Hydrogen peroxide Gas Decontamination. J Microbial Biochem Technol 4: 057-062. doi:10.4172/19485948.1000072

Copyright: (c) 2012 Andersen BM, et al. This is an open-access article distributed under the terms of the Creative Commons Attribution License, which permits unrestricted use, distribution, and reproduction in any medium, provided the original author and source are credited 
Citation: Andersen BM, Hochlin K, Daling JP (2012) Cleaning and Decontamination of Reusable Medical Equipments, Including the use of Hydrogen peroxide Gas Decontamination. J Microbial Biochem Technol 4: 057-062. doi:10.4172/1948-5948.1000072

\begin{tabular}{|c|c|c|}
\hline Medical equipment & Decontamination method or advice & Comments \\
\hline Ventilator & "Clean or replace equipment between use on different patients" & $\begin{array}{l}\text { FAQs about Ventilator-associated } \\
\text { pneumonia } \\
\text { Co-sponsored by SHEA, IDSA,AHA, } \\
\text { APIC, CDC, Joint Commission }\end{array}$ \\
\hline Respiratory therapy equipment & $\begin{array}{l}\text { "Reusable devices or items that touch mucous membranes should, at a } \\
\text { minimum, receive high-level disinfection between patients." }\end{array}$ & $\begin{array}{l}\text { CDC: Sterilization or Disinfection of } \\
\text { Medical Devices. }\end{array}$ \\
\hline $\begin{array}{l}\text { Medical devices that do not touch the patient- or } \\
\text { only intact skin }\end{array}$ & $\begin{array}{l}\text { "-items that do not ordinary touch the patient or touch only intact skin are } \\
\text { not involved in disease transmission, and generally do not necessitate } \\
\text { disinfection between uses on different patients" }\end{array}$ & $\begin{array}{l}\text { CDC: Sterilization or Disinfection of } \\
\text { Medical Devices. }\end{array}$ \\
\hline $\begin{array}{l}\text { Mechanical ventilator- routine damp-dusting of } \\
\text { exterior }\end{array}$ & $\begin{array}{l}\text {-"Prepare the cleaning solution in the bucket in strict accordance with the } \\
\text { manufacturer's instructions - Wipe the surfaces of the ventilator clean, } \\
\text { working from the top to the bottom and paying attention to the } \\
\text { undersides and joints. For greasy or stubborn soiling, use the non-abrasive } \\
\text { pad- Change the cleaning solution and cloth when it becomes soiled- Allow to } \\
\text { dry- Wipe with an alcohol disinfectant wipe- } \\
\text { On completion, dispose of the cloth, clean and dry all equipment and store } \\
\text { safely and tidily in a secure storage area"- }\end{array}$ & $\begin{array}{l}\text { NHS Cleaning Manual 2009, } \\
\text { Department of Health }\end{array}$ \\
\hline CPAP equipment cleaning procedures & $\begin{array}{l}\text { The mask and headgear should be hand-washed twice a week, the grey foam } \\
\text { filter twice a month, the tubing can be washed in warm soapy water rinse and } \\
\text { dried, the humidifier chamber should be drained and hand-washed twice a } \\
\text { week with warm soapy tap water. Rinse thoroughly with clean water. } \\
\text { Unplug and wipe the outside of the CPAP and humidifier unit with a damp } \\
\text { cloth twice a week. }\end{array}$ & $\begin{array}{l}\text { IRS Independent Respiratory Services } \\
\text { Inc, Canada, } 2009\end{array}$ \\
\hline Re-usable & $\begin{array}{l}\text { "The medical device can be used for repeated episodes on different patients, } \\
\text { but requires appropriate decontamination between each use." }\end{array}$ & $\begin{array}{l}\text { NHS Great Yarmouth and Waveney. } \\
\text { Policy on cleaning and disinfection of } \\
\text { equipment, surfaces, environment and } \\
\text { skin. }\end{array}$ \\
\hline Enteral feeding equipment & $\begin{array}{l}\text { "In patients own homes: } \\
\text { It is the users responsibility to keep equipment dust free. If visibly soiled } \\
\text { please clean with warm water and detergent (washing up liquid)" } \\
\text { Syringes- "may be re-used for a specified patient and that patient only - no } \\
\text { longer than } 24 \text { hours-and should be cleaned thoroughly after each use with } \\
\text { warm water, mild detergent and than allowed to air dry." } \\
\text { Returned after use "to central equipment stores for cleaning prior to re-issue" }\end{array}$ & NHS Great Yarmouth and Waveney. \\
\hline Humidifiers & $\begin{array}{l}\text { "Individual patient oxygen humidification systems: Disposable units and } \\
\text { tubing must be used. Use sterile water and change at least daily" }\end{array}$ & NHS Great Yarmouth and Waveney. \\
\hline $\begin{array}{l}\text { Nebulisers, mask and tubing } \\
\text { Oxygen tubing av mask }\end{array}$ & $\begin{array}{l}\text { Single patient use. Cleaned with hot water and detergent between use and } \\
\text { replace weekly. } \\
\text { "Clean the machine as per manufacturers instructions" }\end{array}$ & NHS Great Yarmouth and Waveney. \\
\hline Oxygen machine & $\begin{array}{l}\text {-"Damp dust daily, clean filters weekly when in use and after each patient } \\
\text { use" } \\
\text { Follow manufacturer's instructions }\end{array}$ & NHS Great Yarmouth and Waveney. \\
\hline Suction equipment & $\begin{array}{l}\text { In patients own homes: } \\
\text { Bottles: is disposable- change daily } \\
\text { Machines: -"It is the user's responsibility to keep equipment dust free. If } \\
\text { visibly soiled please clean with warm water and detergent (washing up liquid). } \\
\text { Filter changes and maintenance - carried out by central equipment services } \\
\text { on long term loans as necessary. } \\
\text { When no longer required these should be returned to central equipment } \\
\text { stores for cleaning prior to re-issue. }\end{array}$ & NHS Great Yarmouth and Waveney. \\
\hline
\end{tabular}

Table 1: Decontamination methods or advices concerning medical equipments.

\section{Materials and Methods}

The description of cleaning and maintenance procedures of patient-associated medical equipments is often superficial, as shown by examples in (Table 1) [18-22]. Recommendation for cleaning and decontamination of the internal parts of reusable medical equipment is often missing.

In Norway with 5 million inhabitants, 19 public service centrals of treatment- aids for outpatients are located in different healthcare regions of the country, directed by four regional state enterprises, representing approximately 70000 outpatients and 100000 registered equipments in use. Most outpatients (80\%) are in contact with the service centrals each year [23].

In the Oslo region, 22000 outpatients are using different forms of reusable medical equipments, served by a Service Central of TreatmentAids at Oslo University Hospital, Ullevål. The service includes cleaning, reparation, maintenance and replacement of internal or outer parts of reusable devices. This is done periodically or more often when needed, and always before a new user.

Medical equipments treated are different ventilators, CPAP (often used for sleep apnoea) and other respiratory tract equipments, oxygen concentrators, infusion pumps, nutrition pumps, and suction equipments.

Since 2004, a systematic cleaning and decontamination procedure has been performed for the inner and outer parts of all medical equipment received from outpatients. This has been done by decontamination of non-electric internal parts of the equipment at $85^{\circ} \mathrm{C}$ in a washing machine or using 5\% chloramine manual decontamination. From 2007 on, a $5 \%$ dry mist of hydrogen peroxide gas decontamination has been used in addition $[8,17]$. After finishing the procedure, the equipment is usually delivered to a new user. Service of reusable equipments of 
Citation: Andersen BM, Hochlin K, Daling JP (2012) Cleaning and Decontamination of Reusable Medical Equipments, Including the use of Hydrogen peroxide Gas Decontamination. J Microbial Biochem Technol 4: 057-062. doi:10.4172/1948-5948.1000072

long-term users is performed once a year or more often when needed, for respirators, oxygen concentrators and other ventilation equipments like different CPAPs.

\section{Contaminated and clean side of the service central}

Since 2004 the service of medical equipments at our department has been divided into a contaminated and a clean area. In 2007 a gas decontamination system for medical equipment with $5 \% \mathrm{H}_{2} \mathrm{O}_{2}$ was established and done in a sealed and closed room $[8,17]$.

Contaminated side: All used equipment is delivered to a decontamination room for hydrogen peroxide gas decontamination for six hours (2h per gas cycle) [8]. After gas decontamination, all equipments are opened, internal parts taken out, checked, repaired or changed with new parts, and cleaned inside and outside manually with soap and water or in washing machine. The gas disinfection is often repeated on very dirty equipments, and after the maintenance work.

The cleaned equipment: is packed in separate plastic bags. The further treatment is performed in a clean room. When finished, the equipment is disinfected on the surface and packed into a new bag and placed on a clean store for the next patient.

Registering: Each piece of equipment is registered on a database, including all types of cleaning, gas decontamination and maintenance work.

\section{Personal hygiene and use of personal protective equipment (PPE)}

Hand hygiene and daily change to a new uniform is the standard. Personal protective equipment is used on the contaminated side, like uniform, gloves, mask and room - bound shoes. If the equipment is coming from a patient with infection, the worker is using gown, gloves, mask, goggles, hood, and shoe-covers. Cleaning of rooms and working places is done each day, using wet mopping [13]. All working places and tools used are, in addition, disinfected with alcohol (70\% Antibac) two times a day.

\section{Hydrogen peroxide dry mist decontamination}

The gas decontamination was done in a sealed and closed room, using a system of $5 \%$ dry mist of hydrogen peroxide (Sterinis, Helse og Miljø AS, Østre Aker vei 243, 0976 Oslo), three diffusion cycles, each of $2 \mathrm{~h}$, as described earlier [8]. The robot technology system produces hydrogen peroxide, in electrical charged particles of such a small size (ca 10 microns in diameter) that they circulate freely in the air -as a dry aerosol or fume- making disinfectant accessible to all surfaces. The $\mathrm{H}_{2} \mathrm{O}_{2}$ adheres to particles present in the atmosphere and on surfaces, and form a dry film on these particles. The content of the aerosol container; Sterusil, is hydrogen peroxide 5\%, phosphoric acid $<50$ ppm, silver cations $<50 \mathrm{ppm}$, gum arabica $<1 \mathrm{ppm}$, and bi-osmotic water; $95 \%$. The system consists of a programmable robot that can be pre-programmed to a concentration of hydrogen peroxide aerosol

\begin{tabular}{|c|c|c|c|c|c|}
\hline $\begin{array}{l}\text { Medical equipment and placement of } \\
\text { the spores during decontamination }\end{array}$ & $\begin{array}{l}\text { Spore test; } \\
\text { tested after }\end{array}$ & lus atrop & & $\begin{array}{l}\text { Spore tests } \\
\text { failed }\end{array}$ & Producer or dealer \\
\hline DeVilbiss, Oxygen concentrator & Number & Growth & No growth & $\%$ & $\begin{array}{l}100 \text { DeVillbiss Drive Somerset, Pennsylvania 1550-2125, } \\
\text { USA }\end{array}$ \\
\hline Inside compression & 38 & 7 & 31 & 18.4 & \\
\hline Inside -patient tube & 38 & 17 & 19 & 44.7 & \\
\hline Porta Neb, nebulizer-inhalation & & & & & Philips respironics.Normed AS, Norway \\
\hline Silencer-inside & 38 & 1 & 37 & 2.7 & \\
\hline Patient tube-inside** & 6 & 1 & 5 & 16.7 & \\
\hline Chassis-inner part & 10 & & 10 & 0.0 & \\
\hline Compressor-inside & 35 & 1 & 34 & 2.9 & \\
\hline CR 60, nebulizer- inhalation & & & & & Philips respironics.Normed AS, Norway \\
\hline Patient tube - air out & 38 & 4 & 34 & 10.5 & \\
\hline Compressor-inside & 32 & 2 & 30 & 6.3 & \\
\hline VPAP III ST & & & & & ResMed Norway AS, 1363 Høvik, Norway \\
\hline Inside blow modul & 43 & 1 & 42 & 2.3 & \\
\hline Inside patient tube & 43 & 2 & 41 & 4.7 & \\
\hline Medela Vario suction apparatus & & & & & $\begin{array}{l}\text { Medela Inc. PO Box 660, } 1101 \text { Corporate Drive MCHenry, } \\
\text { IL, } 60050\end{array}$ \\
\hline Innside bottle & 44 & & 44 & 0.0 & \\
\hline Oxygen termos Spirit 300 & & & & & $\begin{array}{l}\text { Mountain Aire Medcal Equipment } 1165 \text { Valley ST, } \\
\text { Colorado Springs, USA }\end{array}$ \\
\hline Card for control & 7 & 5 & 2 & 71.4 & \\
\hline Inside carrier bag & 30 & & $3 v 0$ & 0.0 & \\
\hline Total of spore tests- equipment & 402 & 41 & 359 & 10.2 & \\
\hline Sealed decontamination room & & & & & \\
\hline Ceiling & 43 & & 43 & 0.0 & \\
\hline At the floor, behind the Sterinis robot & 43 & & 43 & 0.0 & \\
\hline Total of spore tests- environment & 86 & & 86 & 0 & \\
\hline
\end{tabular}

*Bacillus atrophaeus Raven 1162504

${ }^{* *}$ Bacillus atrophaeus Raven 1162742 was used in 12 spore test for PortaNebb (1/6 growth in patient tube, 0/6 in compressor), and in 12 spore tests for VPAP III ST- all negative

Table 2: Growth from spore tests placed inside medical equipments and in a sealed room during decontamination with a dry mist of hydrogen peroxide $5 \%$. 
that is dry, depending on the exact volume of the enclosed room. Consumption of disinfectant is $6 \mathrm{ml} / \mathrm{m}^{3}$ for full disinfection [8].

The aerosol-producing robot was placed to get the most effective concentration of dry aerosols, which is ca $2 \mathrm{~m}$ in front and to the sides of the robot. The whole disinfection process was preset on the robot. Each of the three cycles were followed by an increasing contact time that was $30 \mathrm{~min}, 60 \mathrm{~min}$ and $120 \mathrm{~min}$ after one, two, and three cycles, respectively. Each cycle was immediately followed by the preset contact time, which was then immediately followed by the next cycle, etc. The decontamination room was closed during the complete decontamination process, and no persons were present. All ventilation openings were taped in the rooms. The Norwegian Directory of Labour Inspection has set an exposure limit of hydrogen peroxide of $1 \mathrm{ppm}$ (parts per million) during $8 \mathrm{~h}$ exposure, or less than $3 \mathrm{ppm}$ for 15 minutes four times a day. The fume does not persist because of a rapidly gas decomposition.

All reusable medical equipments were run mechanically during the process to draw gas into the motor and other internal parts. Gas leakages were monitored by a ppm - meter for hydrogen peroxide (Drager, USA) in all neighbouring rooms. All tests were negative. During maintenance work the devices were studied for corrosion or other effect of the hydrogen peroxide gas. No corrosion was detected.

\section{Spore control}

Spore controls were done regularly with spores of Bacillus atrophaeus Raven, 1162504 and 1162742 (Raven Biological Laboratories Inc., Nebraska 68127), placed into defined equipments each time to control the effect of decontamination. The same batch number was used for 390/402 spore tests. The defined type of equipment from outpatients was carefully opened by a technician before any cleaning process and the spores were placed on preset places inside patient tubes, at compression areas, inside bottles and inside carrier bags as shown in Table 2. Spore controls were also done for the specific decontamination room (in the ceiling and on the floor behind the Sterinis robot). After the gas decontamination, the spore strips were carefully removed from the equipments, sent blinded to the Department of Sterility Control, Rikshospitalet, Oslo, and cultured for seven days as earlier described $[8,9]$. During a period of three years, regular spore test controls were done for the internal parts of the devices before any cleaning and maintenance work.

\section{Medical equipment from patients with infectious diseases}

The devices from outpatients with suspected lung tuberculosis was not reused for other patients because of failure of dry mist of hydrogen peroxide 5\% gas to kill Mycobacterium tuberculosis [8-10]. Patients with cystic fibrosis did not receive reused equipment.

\section{Growth of microbes from internal parts of the equipment}

From each of 10 different equipments, samples were taken for growth of bacteria, yeasts and fungi before the cleaning and decontamination process. The users had no known infection. The samples were taken aseptically by the technician, sent to the Department of Medical Microbiology, Oslo University Hospital, Ullevål, and studied as a routine test. Ordinary growth media for bacteria and fungi were used.

\section{Results}

The dirtiness and contamination status of reusable medical equipment after the use in outpatients varied, as shown in Figures 1-4. Even outside, the device could be heavily contaminated with dust and biological materials from the patients home, as shown for the oxygen concentrator (Figure 1). It often looked clean outside, but inside it was mostly heavily contaminated as shown for devices of a CPAP (Figure 2), a Cough assistant (Figure 3), and an Autoset CS 2 (Figure 4). It was both difficult and time-consuming to clean and decontaminate all inner parts of devices as shown for the CPAP (Figure 5). In addition, most equipment might contain a rather high level of metallic dust from the brushes.

Gas decontamination with $\mathrm{H}_{2} \mathrm{O}_{2}$ was studied by placing spores inside the medical equipment that was not cleaned before the treatment (Table 2). During a period of three years, regular spore controls were done for the internal parts of the devices before cleaning and maintenance work. The gas killed $90 \%$ of the spore controls inside the medical equipment (Table 2). Some patient tubes could not be run and ventilated good enough with the gas during the decontamination process.

All spore controls set up in the decontamination room were killed by $\mathrm{H}_{2} \mathrm{O}_{2}$. There was not found any leakage of hydrogen peroxide gas to other rooms during the gas disinfection cycles, as controlled by the ppm meter. There was no reported corrosion or other defects on the sensitive parts of the equipment during this procedure.

Microbial samples from ten equipments delivered after use by ten different outpatients, after a shorter or longer user period, were studied for bacteria, yeasts and fungi. Fungi were found in 5 of 10 items (two of them Aspergillus species), yeasts in 2 of 10 and bacteria in 7 of 10 . Two out of ten devices showed no growth by the sample test.

\section{Discussion}

There is a shortage of knowledge about hygiene and infection control concerning reusable medical equipment, and this may in some

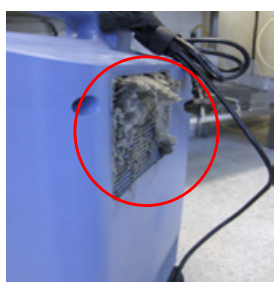

Figure 1: Oxygen concentrator delivered from an outpatient with chronic obstructive lung disease. The air inlet is full of dust from the patients environment.
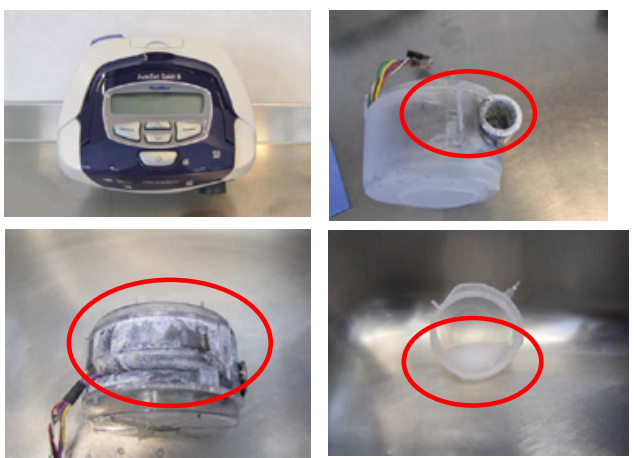

Figure 2: CPAP used by an outpatient. The device looks clean outside, but inside is the machine heavily contaminated with slimy liquid, mucus and biofilm of baceria and fungi. 

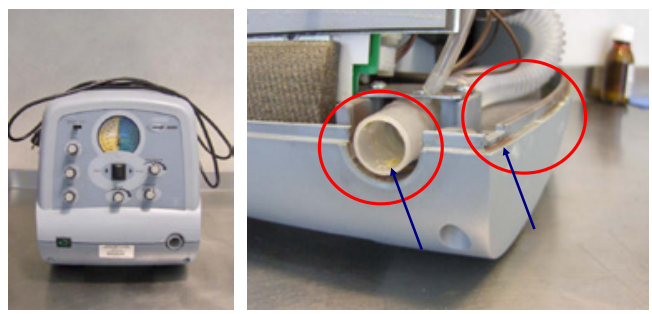

Figure 3: Cough Assistant from an outpatient. Secret from the patient, air filter is missing and there is contamination along the edge of the lid.
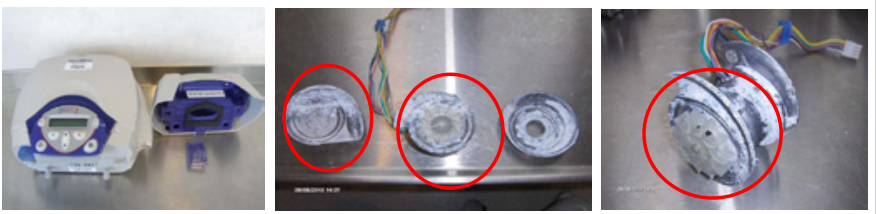

Figure 4: Autoset CS 2 from an outpatient. It looks clean outside, but inside is the device heavily contaminated and partly looks like corrosion.

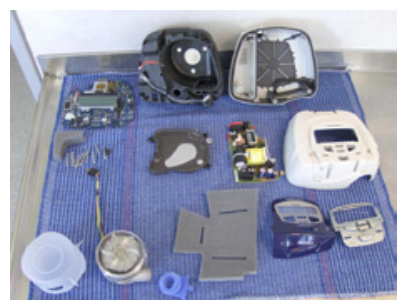

Figure 5: Inner parts of CPAP to be cleaned and controlled before reuse.

situations be critical for the patient, family, health care workers and the environment [18-22]. According to the Norwegian Infection Control $A c t$, written procedures for general infection control and hygiene are required when purchasing, controlling and re-circulating medical equipment in health care: "It is important to establish quality systems that ensure that equipments that can transmit infections are cleaned, disinfected, eventually sterilized, stored, transported and handled in a satisfactory way. The institution should ensure that the equipment included in these procedures are functioning in a satisfactory way [24]". Also personnel handling and controlling this equipment are protected by the same act, which is in accordance with the Norwegian Work and Environment Act, and directives from the European Union [24-26].

Infections from contaminated medical equipment and inadequate disinfection procedures are well known in hospital settings [27-29]. Up to $55 \%$ of ventilator-associated pneumonia (VAP) is estimated to be preventable in US hospitals [30]. A part of this may probably be due to contaminated reusable medical equipment.

This study is a presentation of a combined cleaning, manual and gas decontamination method for reusable medical equipment for outpatients. It is limited by the fact that there is no control group without intervention, and there is no following up of infections among patients. The reason is that a control group with un-cleaned and undecontaminated devices for reuse in outpatients would in Norway be unethical and not in accordance with the law for the patients or the personnel [24-26]. Most public service centrals in Norway are using the combination of manual cleaning and decontamination and in addition the gas disinfection.
International decontamination methods of reusable medical equipment are variable, not well defined and may be dependent on the contract with the producer [18-22]. The control and maintenance work done by the producer is usually not accessible for the user. Therefore it is important with public access to technicians, well educated in infection control and maintenance work, to handle medical equipments [23-25].

Bacterial pathogens have different resistance to germicidal agents [31]. Studies have shown that survivors to germicidal agents, like Pseudomonas aeruginosa and Staphylococcus aureus, are more resistant and also most commonly reported in association with infections [31]. Resistance to disinfectants may be important " - in determining the relative prominence of an organism as an agent responsible for nosocomial infections."[31]. The survival time of microbes in the environment, air and in the internal parts of the medical equipment is also of importance for the transmission of infections. Most pathogenic bacteria, virus and fungi are robust and may survive for months and up to years under dry or wet conditions, like many types of gram negative rods, staphylococci, Aspergillus sp, hepatitis B and C, norovirus, adenovirus aso [32-35].

In our pilot study, eight of ten medical equipments were contaminated with bacteria or fungi. This may be associated with the burden of biological materials, lack of cleaning and air quality in the patient's home. Most equipment draw air from the room into the inner parts of the machine, including dust and dirt from the environment and dried or wet secrete, excrete, slime and blood rests from the patient, as shown in our study. Therefore, the device has to be cleaned and decontaminated before each reuse for other patients, as done in this study.

The hydrogen peroxide dry mist disinfection is done directly on equipments delivered from outpatients - before any further work. This may protect the workers, other equipment and the environment of the service centrals from being contaminated by re-aerosols and contact infection from handling and opening the devices. However, gaseous hydrogen peroxide may have a limited effect on microbes buried in dirt, biofilms or organic materials [29]. In a study by Otter and French, more than 20 strains of dried, nosocomial bacteria and spores, were inactivated by the use of hydrogen peroxide vapour [36] Catalase producing bacteria were most difficult to kill and the effect was dependent on the bacterial quantity treated [36]. They also found that vapourised hydrogen peroxide inactivated MRSA in hospital environment [37].

In our study, spores of Bacillus sp in the decontamination room were easily killed by the hydrogen peroxide dry mist. In addition, most-90\%- of the spores placed inside control equipments under dirty conditions and before cleaning were also killed by the gas. The ability to kill microbes is dependent on high enough concentrations of gas through the systems. The quality of the spores may also vary [38]. The dry mist of hydrogen peroxide - method used in this study did not corrode or destroy the sensitive inner parts of the equipments.

Immune compromised patients and patients with cystic fibrosis should never reuse medical equipment and equipment from patients with suspected tuberculosis should not be reused for other patients since there is still no type of gas decontamination that is well documented to kill Mycobacterium tuberculosis [9,10,39-41].

In conclusion, outpatients have an increasing need for reusable medical equipment, including respiratory tract equipments. The infection control for those devices may be superficial or even be missing. During the use in the patient's home, the devices may act as vacuum 
Citation: Andersen BM, Hochlin K, Daling JP (2012) Cleaning and Decontamination of Reusable Medical Equipments, Including the use of Hydrogen peroxide Gas Decontamination. J Microbial Biochem Technol 4: 057-062. doi:10.4172/1948-5948.1000072

cleaners, drawing air from the environment in addition to biological materials like secrete, excrete and blood rests from the patient. If not cleaned and decontaminated inside between users, the equipment may transmit infectious agents between patients, into service centrals, and may even be brought with the patients to and from healthcare institutions. The increase of the hygienic quality of medical equipment to a satisfactory level is an obligatory requirement in modern medicine.

\section{References}

1. Jane D, Siegel MD, Emily Rhinehart, Marguerite Jackson, Linda, et al. (2006) the Healthcare Infection Control Practices Advisory Committee. Management of Multidrug-Resistant Organisms In Healthcare Settings, CDC.

2. CDC. Frequently Asked Questions for Healthcare Personnel. MultidrugResistant Organisms in Non-Hospital Healthcare Settings.

3. (2010) Detection of Enterobacteriaceae Isolates Carrying Metallo-BetaLactamases. MMWR 59: 750.

4. Yong D, Toleman MA, Giske CG, Cho HS, Walsh TR, et al. (2009) Characterization of a new metallo- $\beta$-lactamase gene, bla $a_{\mathrm{NDM}-1}$, and a novel erythromycin esterase gene carried on a unique genetic structure in Klebsiella pneumoniae sequence type 14 from India. Antimicrob Agents Chemother 53: 5046-5054.

5. (2009) Guidance for Control of Infections with Carbapenem-Resistant or Carbapenemase-Producing Enterobacteriaceae in Acute Care Facilities. MMWR 58: 256-260.

6. Carducci A, Verani M, Lombardi R, Casini B, Privitera G (2011) Environmental survey to assess viral contamination of air and surfaces in hospital settings. J Hosp Infect 77: 242-247.

7. Andersen BM, Banrud H, Bøe E, Bjordal O, Drangsholt F (2006) Comparison of UVC Light and Chemicals for Disinfection of Surfaces in Hospital Isolation Units. Infect Control Hosp Epidemiol: 27: 729-735.

8. Andersen BM, Rasch K, Hochlin F-H, Jensen P, Wismar J-E, (2006) et al Decontamination of rooms, medical equipment and ambulances, using a dry mist of hydrogen peroxide disinfectant. J Hosp Infect 62: 149-155.

9. Andersen BM, Syversen G, Thoresen H, Rasch M, Hochlin K, et al. (2010) Failure of dry mist of hydrogen peroxide $5 \%$ to kill Mycobacterium tuberculosis. J Hosp Infect 76: 80-83.

10. Andersen BM (2011) Does "airborne" hydrogen peroxide kill Mycobacterium tuberculosis? J Hosp Infect 77: 81-83.

11. Davies A, Pottage T, Bennett A, Walker J (2011) Gaseous and air decontamination technologies for Clostridium difficile in the healthcare environment. J Hosp Infect 77: 199-203.

12. Rutala WA, Weber DJ (1999) Disinfection of endoscopes: review of new chemical sterilants used for high-level disinfection. Infect Control Hosp Epidemiol 20: 69-76.

13. Andersen BM, Rasch M, Kvist J, Tollefsen T, Lukkassen R, et al. (2009) Floor cleaning: effect on bacteria and organic materials in hospital rooms. J Hosp Infect 71: 57-65

14. Mulvey D, Redding P, Robertson C, Woodall C, Kingsmore $P$, et al. (2011) Finding a benchmark for monitoring hospital cleanliness. J Hosp Infect 77: 2530.

15. Gralton J, Tovey E, McLaws M-L, Rawlinson WD (2011) The role of particle size in aerosolised pathogen transmission: A review. J Infect 62: 1-13.

16. Tang JW, Noakes CJ, Nielsen PV, Eames I, Nicolle A, et al. (2011) Observing and quantifying airflows in the infection control of aerosol- and airborne transmitted diseases: an overview of approaches. J Hosp Infect 77: 213-222.

17. Berge JA, Hochlin K, Rasch M, Laugerud F, Andersen BM (2008) Technical and medical equipment; cleaning, maintenance and decontamination. In Handbook in hygiene and Infection Control for Hospitals. Oslo University Hospital-Ullevål, Oslo: 635-638.

18. FAQs about "Ventilator-associated pneumonia".

19. CDC. Sterilization or disinfection of medical devices.

20. (2009) NHS. National Patient Safety Agency-National Reporting and Learning Service. The Revised Healthcare Cleaning Manual.

\section{1. (2009) IRS Canada. CPAP Equipment cleaning procedures.}

22. NHS Great Yarmouth and Waveney. Policy on cleaning and disinfection of equipment, surfaces, environment and skin. gyw-pct.infectionpreventio- nhs. net.

23. Norwegian Department of Health and Welfare. NOU 2010-5. Active participation, equality and inclusion. A complete offer. 2010

24. Norwegian Department of Health and Welfare. The Communicable Disease Control Act. 1994 no.55. Protection for infectious diseases. Infection control in health care. 2005 .

25. Norwegian Work and Environment Act. Protection against exposition for biological materials (bacteria, virus fungi aso), on the workplace. December 19, 1997.

26. Directive 2000/54/EF of the European Parliament and of the Council of 18 September 2000 concerning protection against exposition for biological materials (bacteria, virus fungi etc), on the workplace. 2000.

27. Kalpoe JS, Hogenbirk K, Maarseveen van NM, Gesink-Van der Veer BJ, Kraakman ME, et al. (2008) Dissemination of Bacillus cereus in a paediatric intensive care unit traced to insufficient disinfection of reusable ventilator airflow sensors. J Hosp Infect 68: 341-347.

28. Savey A, Simon F, Izopet J, Lepoutre A, Fabry J, et al. (2005) A large nosocomial outbreak of hepatitis $\mathrm{C}$ virus at a hemodialysis center. Infect Control Hosp Epidemiol 26: 752-760.

29. Rutala WA, Weber DJ (2008) Guideline for disinfection and sterilization in healthcare facilities. Atlanta: Centers for Disease Control and Prevention

30. Umscheid CA, Mitchell MD, Doshi JA, Aagarwal R, Williams K, et al. (2011) Estimating the proportion of healthcare-associated infections that are reasonably preventalbe and the related mortality and costs. Infect Control Hosp Epidemiol 32: 101-114

31. Sagripanti JL, Eklund CA, Trost PA, Jinneman KC, Abeyta C Jr, et al. (1997) Comparative sensitivity of 13 species of pathogenic bacteria to seven chemical germicides. Amer J Infect Control 25: 335-339.

32. Weber D, Rutala WA (2001) The emerging nosocomial pathogens Cryptosporidium, Escherichia coli 0157:H7, Helicobacter pylori, and hepatitis C: Epidemiology, environmental survival, efficacy of disinfection, and control measures. Infect Control Hosp Epidemiol 22: 306-315.

33. Wilson APR, Hayman S, Folan P, Ostro PT, Birkett A, et al. (2006) Compute keyboards and the spread of MRSA. J Hosp Infect 62: 390-392.

34. Wagenvoort JHT, Penders RJR (1997) Long-term in-vitro survival of an epidemic MRSA phage-group III-29 strain. J Hosp Infect 35: 322-324

35. Sizun J, Yu MWN, Talbot PJ (2000) Survival of human coronaviruses 229E and OC43 in suspension and after drying on surfaces: a possible source of hospitalacquired infections. J Hosp Infect 46: 55-60.

36. Otter JA, French GL (2009) Survival of nosocomial bacteria and spores on surfaces and inactivation by hydrogen peroxide vapour. J Clin Microbiol 47 205-207.

37. French GL, Otter JAS, Shannon KP, Adams NMT, Parks MJ, et al. (2004) Tackling contamination of the hospital environment by methicillin resistan Staphylococcus aureus (MRSA): a comparison between conventional terminal cleaning and hydrogen peroxide vapour decontamination. J Hosp Infect 57: 31-37

38. Fraise A (2011) Currently available sporicides for use in healthcare, and their limitations. J Hosp Infect 77: 210-212.

39. Hall L, Otter JA, Chewins J, Wengenack NL (2007) Use of hydrogen peroxide vapour for deactivation of Mycobacterieum tuberculosis in a biological safety cabinet and a room. J Clin Microbiol 45: 810-815.

40. Kahnert NA, Seiler P, Stein M, Aze B, McDonnel G, et al. (2005) Decontamination with vaporized hydrogen peroxide is effective against Mycobacterium tuberculosis. Lett Appl Microbiol 56: 448-452.

41. Grare M, Dailloux M, Simon L, Dimajo P, Laurain C (2008) Efficacy of dry mist of hydrogen peroxide (DMHP) against Mycobacterium tuberculosis and use of DMHP for routine decontamination of biosafety level 3 laboratories. J Clin Microbiol 46: 2955-2958. 